\title{
Dynamics of prokaryotic picoplankton community in the central and southern Adriatic Sea (Croatia)
}

\author{
Danijela Šantić • Nada Krstulović • Mladen Šolić • \\ Marin Ordulj · Grozdan Kušpilić
}

Received: 28 March 2012/Revised: 28 August 2012/Accepted: 16 October 2012/Published online: 6 November 2012

(C) Springer-Verlag Berlin Heidelberg and AWI 2012

\begin{abstract}
This paper addresses the dynamics of the prokaryotic picoplankton community in the coastal and open sea areas of the central Adriatic and in the coastal area of the southern Adriatic. This involved the study, from January to December 2005, of bacteria (total number of non-pigmented bacteria; high nucleic acid content (HNA) bacteria; low nucleic acid content (LNA) bacteria), cyanobacteria (Synechococcus and Prochlorococcus) and heterotrophic nanoflagellates. During the warmer seasons, in the mainly oligotrophic area under investigation into the Adriatic Sea, bacterial densities and bacterial production have shown an increase in values and domination of the LNA group of the bacterial population. In contrast, in those areas influenced by karstic rivers, the domination of HNA bacteria in total abundance of non-pigmented bacteria and high values of bacterial production was estimated throughout the investigated period. Our results show the importance of both HNA and LNA bacterial groups in the total bacterial activity throughout the investigated area. The biomass of bacteria was mostly predominant in the prokaryotic community, while within the autotrophic community Synechococcus biomass mostly predominated. During the warmer seasons, an increase in autotrophic biomass was observed in relation to non-pigmented biomass. The importance of predation in controlling bacteria
\end{abstract}

Communicated by G. Gerdts.

D. Šantić $(\bowtie) \cdot$ N. Krstulović · M. Šolić · G. Kušpilić Institute of Oceanography and Fisheries,

P. O. Box 500, Split, Croatia

e-mail: segvic@izor.hr

M. Ordulj

University Department of Marine Studies,

University of Split, Livanjska 5/III, Split, Croatia by heterotrophic nanoflagellates was pronounced during the warmer period and in the coastal areas.

Keywords Synechococcus . Prochlorococcus . Heterotrophic bacteria · HNA - LNA · Adriatic Sea

\section{Introduction}

Non-pigmented bacteria and photosynthetic picoplankton are ubiquitous and represent numerous and active components of the marine ecosystem. Bacteria play an important role through their assimilation of dissolved organic matter (Cole et al. 1988) and by the decomposition of organic matter and through the transformation of inorganic compounds into forms suitable for primary producers (Ducklow et al. 1986). Photosynthetic picoplankton appears to be an essential component of marine ecosystems and one of their representatives, cyanobacteria Synechococcus (Waterbury et al. 1979) and Prochlorococcus (Chisholm et al. 1988) significantly contribute to phytoplankton biomass, especially in oligotrophic areas like the Mediterranean Sea (Magazzù and Decembri 1995; Agawin and Agustí 1997). In addition, the application of flow cytometry has expanded the knowledge of the microbial community members and has permitted discrimination within cyanobacterial cells (Synechococcus and Prochlorococcus) and non-pigmented bacterial cells based on different deoxyribonucleic acid content (Olson et al. 1993; Gasol and Del Giorgio 2000). There is much literature concerning the distribution and dynamics of non-pigmented cells within the investigated area of the Adriatic Sea. A few reports of Synechococcus and Prochlorococcus exist (Fuks et al. 2005; Ninčević et al. 2006; Radić et al. 2009; Šilović et al. 2011; Šantić et al. 2011), but simultaneous observations of Synechococcus, 
Prochlorococcus and non-pigmented bacteria are absent. The objectives of this study were to describe the seasonal cycles of non-pigmented prokaryotes, indicate the possible role of HNA and LNA bacteria in bacterial activity in the investigated areas, show the relationship between biomasses of autotrophic and non-pigmented prokaryotes and identify the role of heterotrophic nanoflagellates in controlling the bacterial population.

\section{Materials and methods}

\section{Study area}

The Adriatic Sea is the northernmost basin in the Mediterranean, $800 \mathrm{~km}$ long and 200-250 km wide. Bathymetry divides the basin into three parts: a broad northern Adriatic shelf with an average depth of $40 \mathrm{~m}$, the central Adriatic with depressions as deep as $280 \mathrm{~m}$, and connected to the southern Adriatic circular basin over the Palagruža Sill. The coastal area investigated is located in the central and southern Adriatic basin, covering the coastal zone from Zadar to Dubrovnik and is partly under the influence of the karstic rivers: Krka (Šibenik area), Jadro (Kaštela Bay), Žrnovnica, Cetina (Split area), Neretva (Ploče area) and Trebišnjica (Dubrovnik area). In the open sea, samples were collected from station CA001 located in the Jabuka Pit, CA003 located in the open sea area of Sibenik and at station CA009 located near the island of Vis (Fig. 1).

\section{Sampling}

Sampling was mostly at monthly intervals from January 2005 to December 2005 on RV Bios using Niskin bottles (5 1). Samples were collected at several depths between the surface and the bottom (at 5- to 10-m intervals for the upper $50 \mathrm{~m}$ and at 75, 100, 168, 200 and $260 \mathrm{~m}$ at deepest station). A SeaBird 25 CTD profiler recorded temperature and salinity data. Nutrient concentrations $\left(\mathrm{NO}_{3}{ }^{-}, \mathrm{NO}_{2}{ }^{-}\right.$, $\mathrm{NH}_{4}{ }^{+}$, total dissolved inorganic nitrate/DIN/and soluble reactive phosphate/SRP) were determined using the autoanalyser modified method by Grasshof (1976).

\section{Flow cytometry}

Abundances of Synechococcus, Prochlorococcus and nonpigmented bacteria were determined using flow cytometry (Marie et al. 1997). For flow cytometry counts of autotrophic cells, $2 \mathrm{ml}$ of preserved samples in $0.5 \%$ gluteraldehyde was frozen at $-80{ }^{\circ} \mathrm{C}$ and stored until analysis (5-10 days), while samples for bacteria were preserved in $2 \%$ formaldehyde and stored at $4{ }^{\circ} \mathrm{C}$ until analysis (5-10 days).
Abundances of SybrGreen I-stained non-pigmented bacteria were determined using flow cytometry (Marie et al. 1997). Samples of $1 \mathrm{ml}$ without replicas were analysed on a Beckman Coulter EPICS XL-MCL with a high flow rate from 1 to $1.2 \mu \mathrm{L} \mathrm{s}^{-1}$, and the analysed volume was calculated by acquisition time. To standardise the fluorescence intensity of the cells, $1.0-\mu \mathrm{m}$ yellow-green beads were added (Level-III Epics Division of Coulter Corporation Hialeah, Florida). Two groups of bacteria were distinguished according to their relative green fluorescence as a proxy for the nucleic acid content (Jochem 2001), referred to as high nucleic acid (HNA) and low nucleic acid bacteria (LNA) and light scattering.

Autotrophic cells were separated into two groups of cyanobacteria (Synechococcus and Prochlorococcus) and were distinguished according to light scattering, red emission of cellular chlorophyll content and orange emission of phycoerythrin-rich cells. Biomasses of Synechococcus, Prochlorococcus and heterotrophic bacteria were calculated by using the following volume-to-carbon conversion factors: $250 \mathrm{fg} \mathrm{C}^{-1} \mathrm{Cll}^{-1}$ for Synechococcus, $53 \mathrm{fg} \mathrm{C}$ cell $^{-1}$ for Prochlorococcus and $20 \mathrm{fg} \mathrm{C}^{-1 l^{-1}}$ for non-pigmented bacteria (Zhang et al. 2008).

Bacterial cell production was measured from DNA synthesis based on incorporation rates of ${ }^{3} \mathrm{H}$-thymidine (Fuhrman and Azam 1982). Conversion factors (CF) for bacterial production were calculated from bacterial cell numbers and ${ }^{3} \mathrm{H}$-thymidine incorporation during bacterial growth in $1-\mu \mathrm{m}$ pre-filtered seawater (Riemann et al. 1987): $\mathrm{CF}=\left(N_{2}-N_{1}\right) /^{3} \mathrm{H}$ where $N_{1}$ and $N_{2}$ are the numbers of bacteria at the beginning and the end of the experiment, and ${ }^{3} \mathrm{H}$ is the integrated ${ }^{3} \mathrm{H}$-thymidine incorporation rate during the experiment. The number of heterotrophic nanoflagellates (HNF) was estimated using epifluorescence microscopy. Samples were stained with 4'-6-diamidino-2-phenylindole (DAPI) for $10 \mathrm{~min}$ and filtered through polycarbonate filters with $0.8 \mu \mathrm{m}$ pore diameters (Milipore, Ireland). Microscope slides were examined with an Olympus microscope under UV light at a magnification of 1,000X (Porter and Feig 1980).

Methods for determination of regulation mechanisms in the prokaryotic community

Relationships between abiotic and biotic factors and the abundance of autotrophic and heterotrophic prokaryotes were determined using the Pearson's rank correlation index.

To examine the regulation of bacteria by predation, data were analysed using an empirical model (Gasol 1994). The simultaneous observations of the abundance of bacteria and heterotrophic nanoflagellates (HNF) are plotted on a loglog graph, which provides information about coupling 

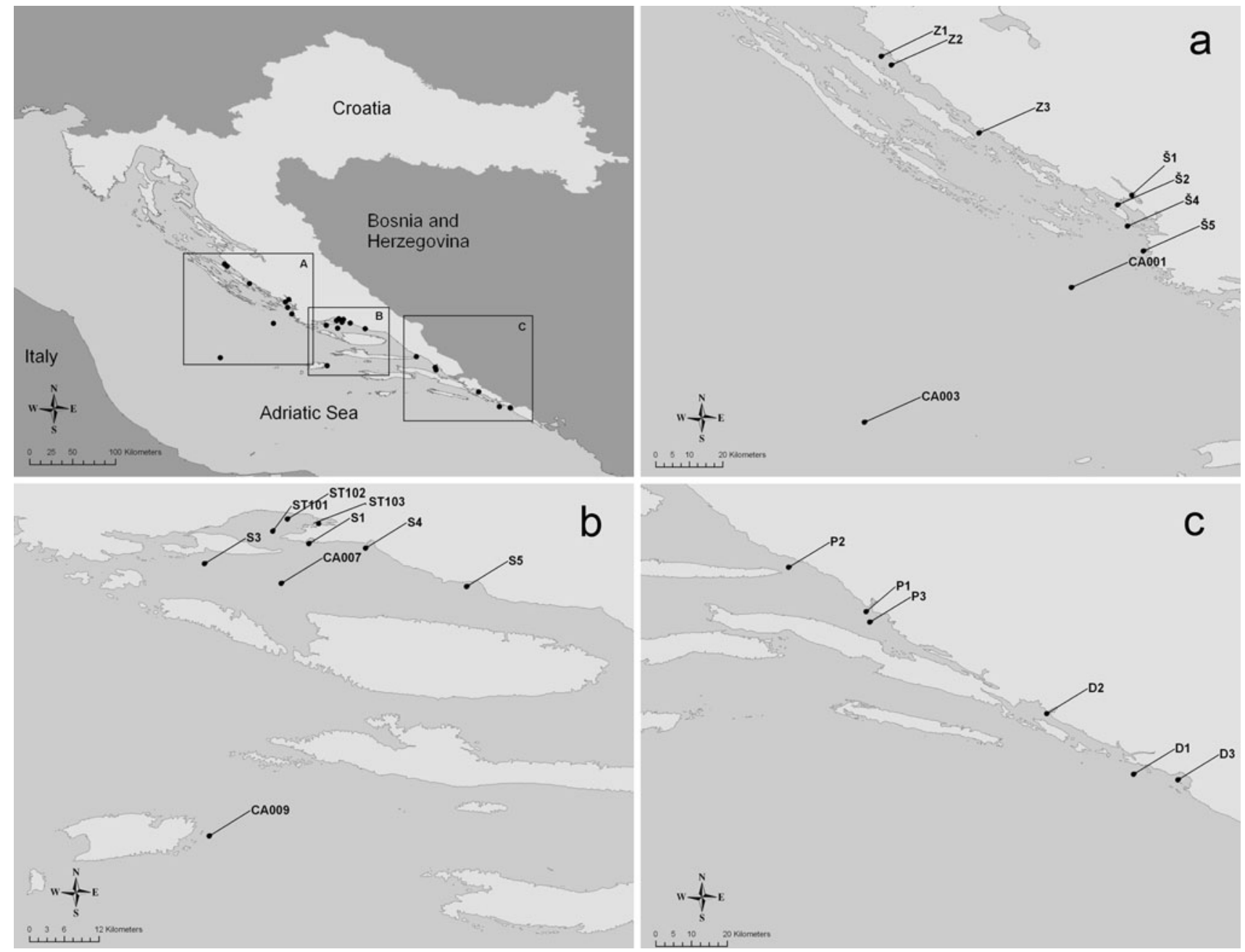

Fig. 1 Study area with sampling stations. a Coastal areas: Zadar (Z1-Z3), Šibenik $(\check{S} 1-\check{S} 5)$ and open sea area $(C A 001, C A 003)$ b coastal areas: Kaštela Bay (ST101-ST103), Split $(S 1-S 5$, CA007) and open sea area (CA009) c coastal areas: Ploče $(P 1-P 3)$, Dubrovnik $(D 1-D 3)$

between bacterial and HNF abundance. The graph includes an empirically determined maximum attainable abundance (MAA) line (based on a large database from a variety of systems) depicting the HNF abundance that could be attained at a given bacterial abundance $(\max \log \mathrm{HNF}=$ $-2.47+1.07 \log$ bacterial abundance) and a mean realised abundance (MRA) line. The points close to the MAA line indicate strong coupling between the bacteria and HNF, which according to Gasol (1994), could be interpreted as strong predation on the bacteria. The points that lie well below the MRA line indicate conditions when bacterial abundance was not controlled by HNF grazing. Therefore, distance (D) values (differences between the maximum and realised HNF abundances at different bacterial concentrations) represent a good indicator of the importance of HNF predators in controlling bacterial abundance. The distance (D) between the maximum and actual measured HNF abundance, for each bacterial abundance value, shows the degree of uncoupling between bacteria and their predators and is surrogate for the grazing pressure of HNF on bacteria. Low $\mathrm{D}$ values mean strong coupling between the abundance of bacteria and HNF, while high D values mean no or low coupling between bacteria and HNF.

\section{Results}

Physicochemical conditions of seawater

In the investigated areas, an isothermal period was obtained from January to April and again in December, while thermal stratification of the water column began in May and lasted until September (Table 1). The lowest values and widest ranges of temperature and salinity were recorded in the areas of Šibenik, Kaštela Bay, Split and Ploče, mostly due to the influence of the river Krka and to a lesser 


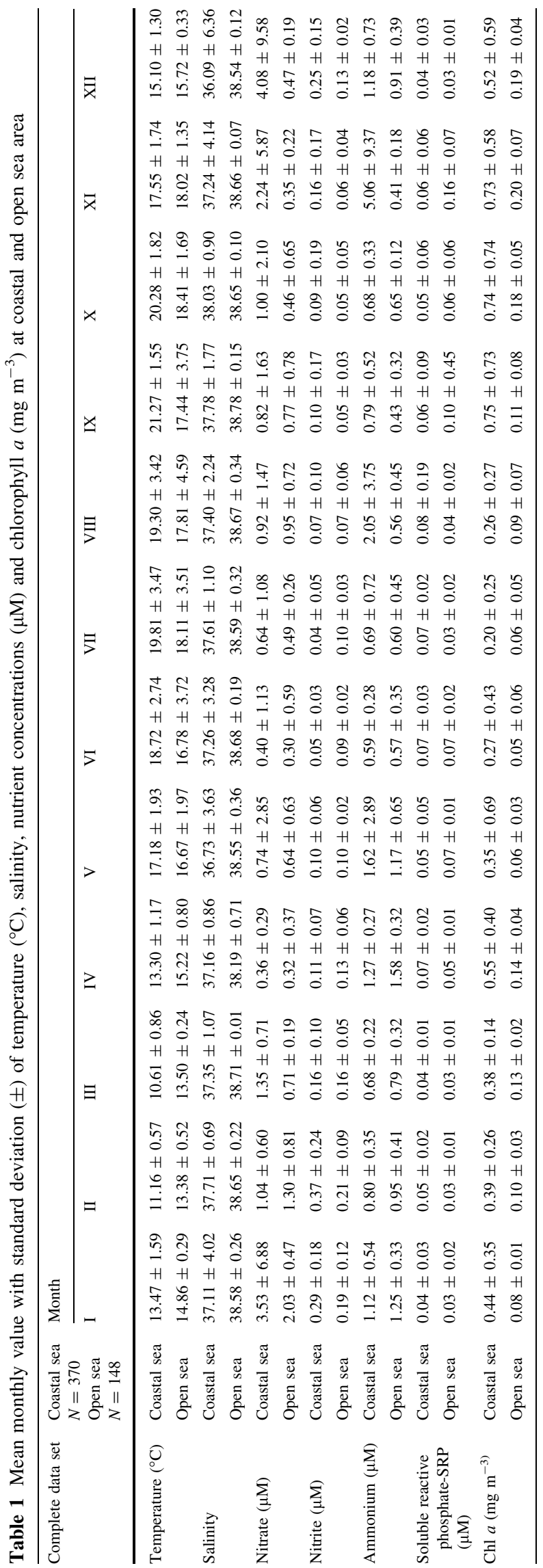

extent, the rivers Jadro, Žrnovnica, Cetina and Neretva (Morović et al. 2006). Nitrates and nitrites in the investigated areas showed increased values in January to February and in December. Values of soluble reactive phosphates at the coastal sea stations were uniform during the isothermal and stratified periods. The highest concentration of ammonium in the coastal areas was detected in November, but high values were also recorded in May and August. In the open sea areas, slightly increased values of ammonium were detected in the period from April to May. Increased values of chlorophyll $a$ were determined in the period from September to December with higher concentrations in coastal areas compared with the open sea (Table 1).

\section{Abundance of non-pigmented bacteria}

Average monthly abundance of bacteria, obtained as the average value from the surface to the bottom layers of the investigated stations, ranged from $0.24 \times 10^{6}$ to $1.3 \times 10^{6}$ cells $\mathrm{mL}^{-1}$ in the central and southern coastal areas and in the open sea ranged from $0.23 \times 10^{6}$ to $0.63 \times 10^{6}$ cells $\mathrm{mL}^{-1}$ (Fig. 2). Seasonal distribution of non-pigmented bacteria in the coastal areas has shown an increased abundance during the warmer seasons and lower abundance during the colder seasons, with pronounced variations in bacterial densities in relation to open sea area (Fig. 2). Comparing all investigated areas, the highest numbers of non-pigmented bacteria were found in the Kaštela Bay area (Table 2).

Percentage of HNA bacteria in the community of non-pigmented bacteria

The average monthly percentage of HNA bacteria in the central and southern coastal areas ranged from 26 to $83 \%$, while in the open sea HNA ranged from 28 to $65 \%$. Different temporal patterns were found for HNA and therefore for LNA bacterial groups. Seasonal distribution mostly showed the prevalence of the HNA group during the colder seasons and a prevalence of LNA bacteria, or equal proportions of the LNA and HNA groups, in the bacterial community during spring and summer. However, a prevalence of the HNA group in the bacterial community during all four seasons was found in the coastal areas directly influenced by rivers (Fig. 3), specifically in the Kaštela Bay (Jadro) and Šibenik areas (Krka). Comparing the investigated areas with the annual average, variations in the proportion of HNA bacteria were mostly more pronounced in the coastal sea areas compared with the open sea area. The annual average at the open sea stations CA001 and CA003 showed percentages of HNA bacteria less than $50 \%$ (Table 2). 

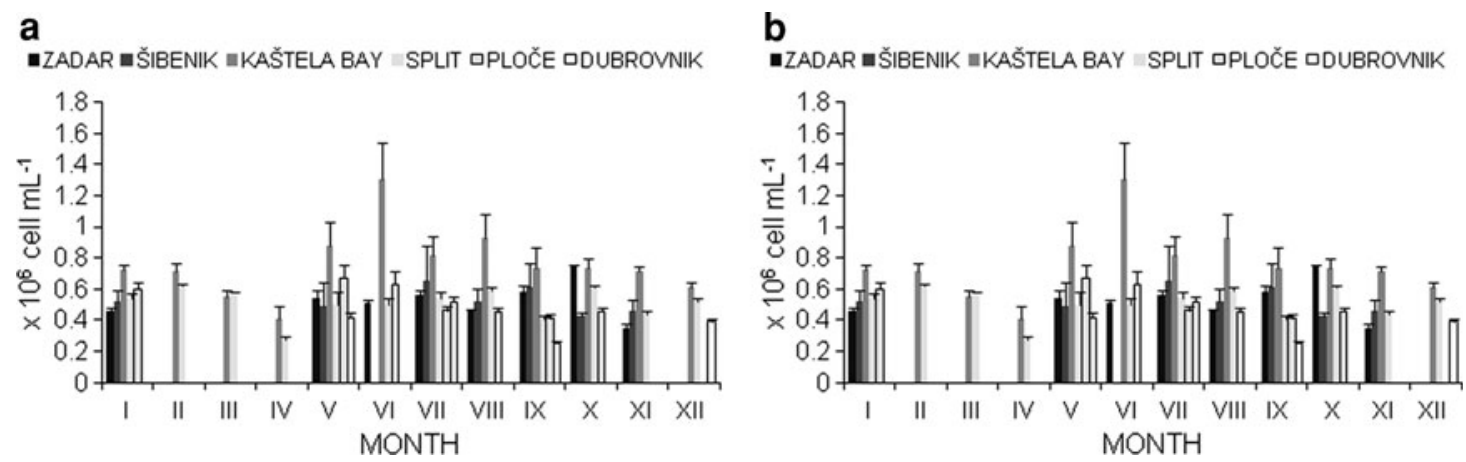

Fig. 2 Seasonal fluctuations of non-pigmented bacteria. a Coastal areas $\mathbf{b}$ open sea station. Average values (column, line with markers) and positive standard error (bars) are presented. The missing sampling points show that there was no sampling
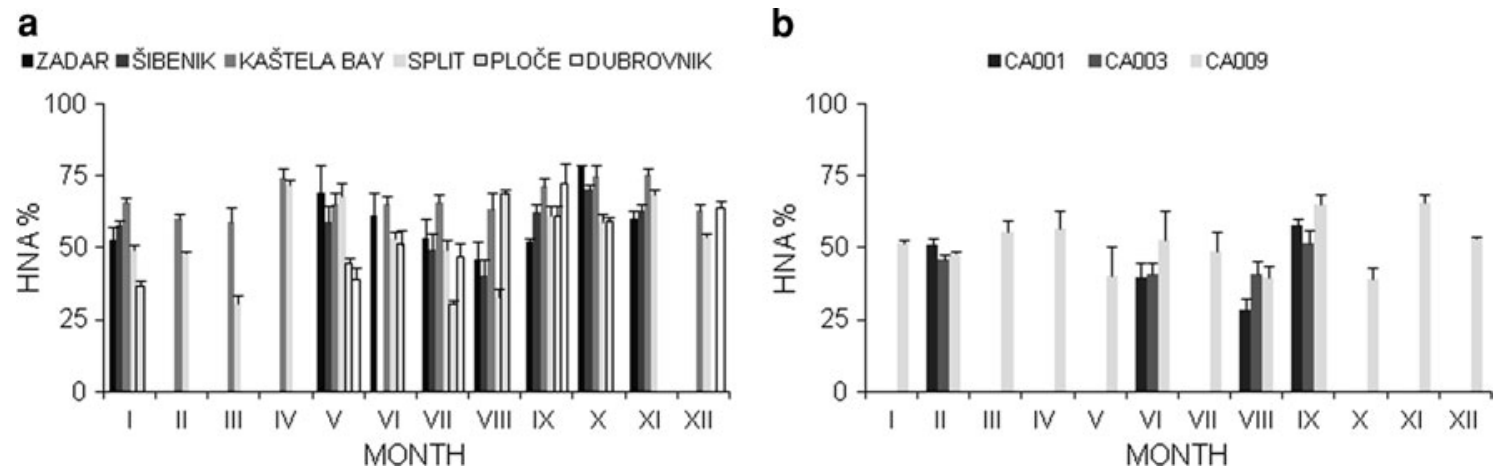

Fig. 3 Seasonal fluctuations of HNA \%. a Coastal areas b open sea stations. Average values (column, line with markers) and positive standard error (bars) are presented. The missing sampling points show that there was no sampling

Relationship of bacterial production and the contribution of HNA bacterial group

The average monthly values of bacterial production in the central and southern coastal areas ranged from $0.03 \times 10^{4}$ to $2.8 \times 10^{4}$ cells $\mathrm{mL}^{-1} \mathrm{~h}^{-1}$ and in the open sea ranged from $0.06 \times 10^{4}$ to $2.71 \times 10^{4}$ cells $\mathrm{mL}^{-1} \mathrm{~h}^{-1}$ (Fig. 4). Seasonal distribution of bacterial production in the coastal areas from Zadar to Split shows increased bacterial productivity during the summer. The second highest values were found in the area of Sibenik during the spring and in the area of Split during the winter. In the area of Ploče, high values of bacterial production were found in January and December. In the southern coastal region, increased bacterial production was determined during the seasons of spring and autumn. Distribution at the open sea stations CA001 and CA003 showed increased bacterial productivity in the spring and at CA009, during winter and autumn (Fig. 4).

Comparing the investigated areas with the annual average, variations in bacterial production in the coastal and open sea areas were more pronounced in the area influenced by rivers Krka (Šibenik area) and less pronounced in the southern part of coastal sea (Table 2).

In order to examine bacterial activity, this study observed bacterial productivity in relation to seasonal distribution of the HNA and LNA bacterial groups. The analysis of these two bacterial groups in relation to bacterial productivity in the coastal and open sea regions showed a simultaneous increase in the percentage of the LNA group and bacterial production (Figs. 3, 4). However, exceptions with a prevalence of the HNA group in the bacterial community during the highest values of bacterial productivity were found in those areas influenced by the Krka and Jadro Rivers (Figs. 3, 4). A comparison of all of the investigated areas of the one-year survey showed that the HNA bacterial group was dominant in the bacterial population in coastal areas over values of bacterial production ranging from $0.27 \times 10^{4}$ to $0.89 \times 10^{4}$ cells $\mathrm{mL}^{-1} \mathrm{~h}^{-1}$. However, in the open sea areas, the LNA bacterial group was mostly prevalent in the bacterial population over values of bacterial production ranging from $0.53 \times 10^{4}$ to $0.89 \times 10^{4}$ cells $\mathrm{mL}^{-1} \mathrm{~h}^{-1}$ (Table 2).

Biomass of non-pigmented bacteria in relation to biomasses of Synechococcus and Prochlorococcus

The biomass of the prokaryotic community throughout the studied area was mainly dominated by non-pigmented prokaryotes, except during the spring in the Dubrovnik area and during winter at the open sea station CA003, when the 
biomass of autotrophic prokaryotes predominated over non-pigmented prokaryotes (Fig. 5). Average seasonal values of non-pigmented prokaryotic biomass in the coastal area ranged from 7.87 to $22.27 \mu \mathrm{gC} \mathrm{L}^{-1}$ and in the open sea from 4.60 to $9.60 \mu \mathrm{gC} \mathrm{L}^{-1}$. The values of the biomasses as well as their abundances showed seasonality, mostly demonstrating higher values during the warmer seasons (Fig. 5).

Influencing factors on prokaryotic picoplankton

In the investigated area, correlations between bacterial parameters with temperature and inorganic nutrients were weak or not statistically significant (Table 3 ). The relationship between HNF as a main predator of bacteria and the bacteria was described by distance points (D) obtained by the Gasol model (1994). Thus, lower D values show higher predation pressure and vice versa. Results indicate that the impact of HNF was more pronounced during the warmer season (Fig. 6). Comparing coastal and open sea areas, the strongest associations between $\mathrm{HNF}$ and the bacteria were found in the coastal areas of Šibenik, Ploče and Dubrovnik (Fig. 6).

In addition to a predator-prey relationship, other relationships within the prokaryotic community in the study area were also identified. In both thermal conditions of the water column, bacterial abundance was positively correlated with Prochlorococcus abundance (Table 3). During colder periods, in the coastal sea areas, a positive correlation between bacterial abundance and concentration of chlorophyll $a$ (chl $a$ ) was determined. During warmer periods, in the open sea areas, a negative correlation between bacterial production and concentration of chl $a$ was observed.

\section{Discussion}

The abundance of non-pigmented bacteria in most parts of the study area was lower than $10^{6}$ cells $\mathrm{mL}^{-1}$. According to bacterial density, the investigated area of the Adriatic Sea is mainly oligotrophic (Cotner and Biddanda 2002). The exceptions are those areas under direct influence of the Rivers Krka (Šibenik area) and Jadro (Kaštela Bay), where abundances of non-pigmented bacteria were more than $10^{6}$ cells $\mathrm{ml}^{-1}$. The obtained values of chlorophyll $a$ were in a range from 0.02 to $4.73 \mathrm{chl} a \mathrm{~m}^{-3}$ with the highest values in Kaštela Bay $\left(1.53 \mathrm{chl} a \mathrm{~m}^{-3}\right)$ and the Šibenik area (4.73 $\mathrm{chl} a \mathrm{~m}^{-3}$ ), which describes the investigated area as mostly oligotrophic with mesotrophic and eutrophic parts (Marasović et al. 2006). During the investigation, seasonal distribution in the bacterial community in the coastal areas was determined with maxima in the spring-summer period 


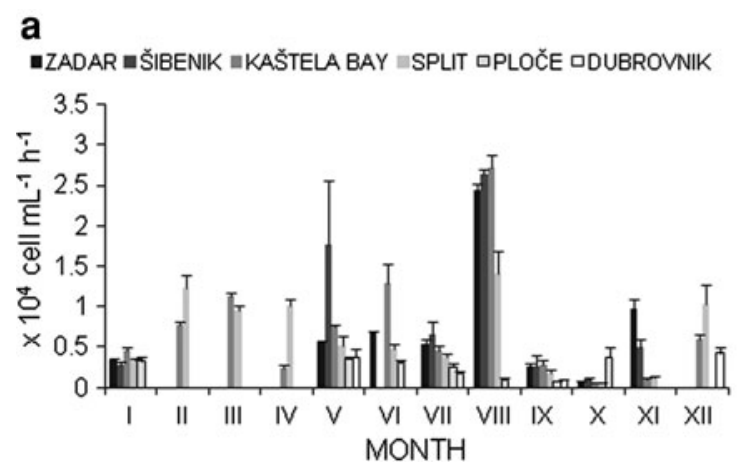

b

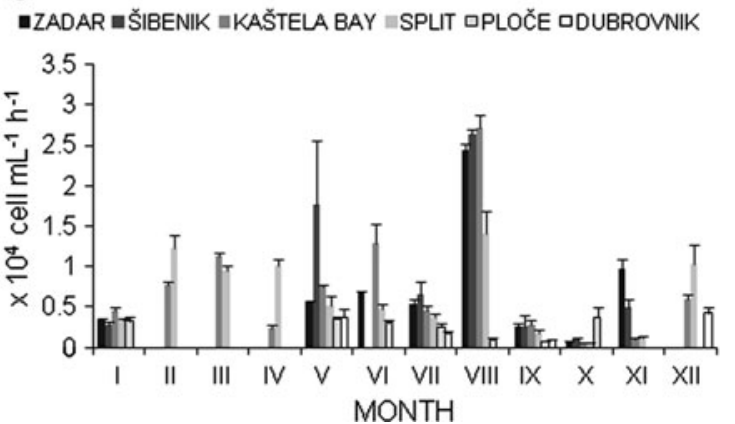

Fig. 4 Seasonal fluctuations of bacterial production. a Coastal areas b open sea stations. Average values (column, line with markers) and positive standard error (bars) are presented. The missing sampling points show that there was no sampling

and minima during the winter, which confirms previous reports on the central Adriatic (Krstulović 1992; Šolić et al. 2001). Seasonal distribution of non-pigmented bacteria at the open sea stations was not as pronounced as the seasonal distributions of bacteria in the Bay of Biscay (Calvo-Díaz and Morán 2006).

Generally, within the bacterial community, the HNA group predominated in eutrophic and mesotrophic areas, whilst the LNA group predominated in oligotrophic environments (Zubkov et al. 2004; Morán et al. 2007). The predominance of the LNA group in oligotrophic conditions can be explained by the high surface area to volume ratio of the cell (Button 1998; Jochem et al. 2004), which facilitates successful survival in poor conditions. However, the prevalence of an individual bacterial group in different environmental conditions could be the result of different life strategies. Members of the HNA bacterial group with large genomes are able to cope with a wide variety of environmental conditions, whilst the LNA group with a small genome occupy narrow ecological niches (Schattenhofer et al. 2011). In this paper, the domination of the HNA bacterial group in the bacterial community was established in areas that have a high trophic level and which are directly influenced by rivers. Thus, our finding is consistent with other research that found that rivers directly influence the dominance of the HNA over the LNA group in eutrophic areas (Li et al. 1995; Šolić et al. 2009). Furthermore, the annual average of the investigated oligotrophic open sea stations showed percentages of HNA bacteria below $50 \%$. This is in accordance with the predominance of the LNA group over HNA, which has also been established for other oligotrophic areas, such as the Celtic Sea, Gulf of Mexico and the Atlantic (Zubkov et al. 2001; Jochem et al. 2004; Andrade et al. 2007).

The seasonal distribution in all investigated oligotrophic areas showed the dominance of the LNA group in the bacterial community mostly during the summer season and dominance of the HNA group during the colder seasons, as described previously in the literature (Grégori et al. 2001;
Calvo-Díaz and Morán 2006). The domination of LNA cells during the warmer seasons can be attributed to selective grazing (Šimek and Chrzanowski 1992; Jürgens and Matz 2002), or better adaptation to oligotrophic conditions (Kjelleberg et al. 1993).

Historically, it was thought that the HNA bacteria were the active part of the microbial community, and the LNA were the inactive or dead part (Zweifel and Hagström 1995; Gasol and Morán 1999), and recent studies have confirmed the importance of the activity of the HNA group in the NW Mediterranean Sea (Mével et al. 2008). However, a number of papers have shown that the LNA group also contributes to the activity of bacterioplankton in the marine ecosystem (Grégori et al. 2001; Li and Dickie 2001; Zubkov et al. 2001; Jochem et al. 2004). Some authors have also shown that the LNA group successfully consumes nutrients and amino acids (Zubkov et al. 2006; Mary et al. 2006) and demonstrates a high-specific growth rate that can exceed the growth rate of HNA bacteria in oligotrophic conditions (Longnecker et al. 2005; Mary et al. 2006). In this study, bacterial activity was observed through seasonal distribution of bacterial productivity in relation to the percentage of the HNA and LNA bacterial groups. At the same time, it was determined that LNA values were higher than $50 \%$ with increased values of bacterial production, which is consistent with previous results from the Atlantic (Morán et al. 2002, 2004). However, in the areas directly influenced by karstic rivers, the HNA bacterial group was dominant throughout the study as well as in areas directly influenced by inflowing rivers (Casotti et al. 2000; Jochem et al. 2004) during all four seasons, as reported by Longnecker et al. (2006). Our results indicate the relative importance of both bacterial groups in bacterial production and activity.

Data regarding abundance and seasonal distribution of Synechococcus and Prochlorococcus for the same period and same investigated stations have been previously published (Šantić et al. 2011). This paper showed the relationship between biomasses of autotrophic and 

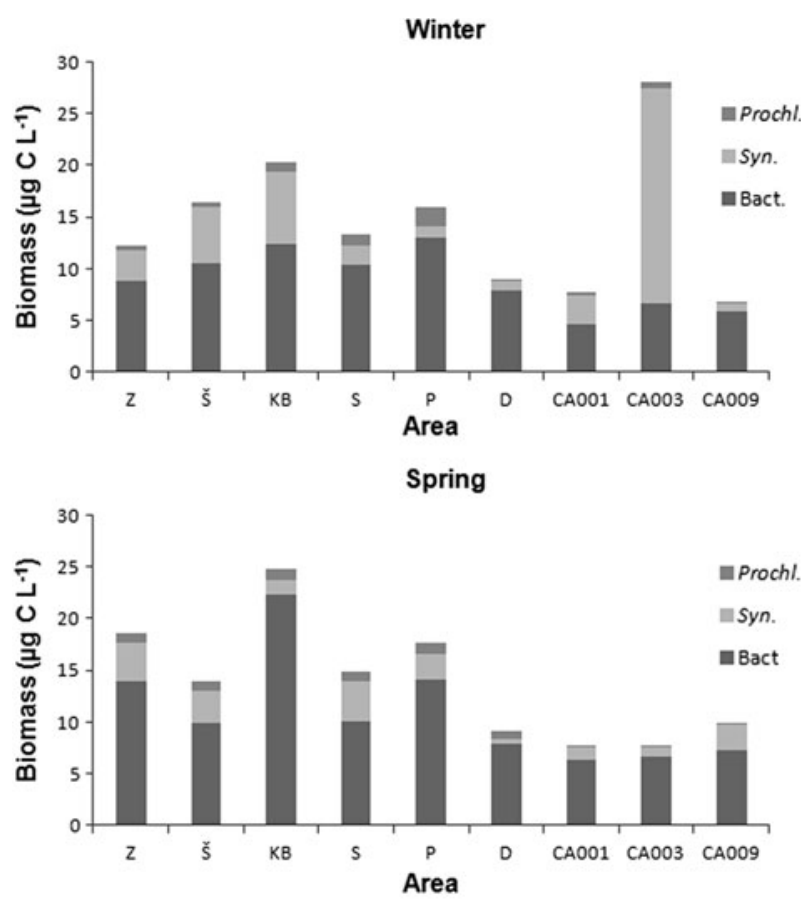

Summer
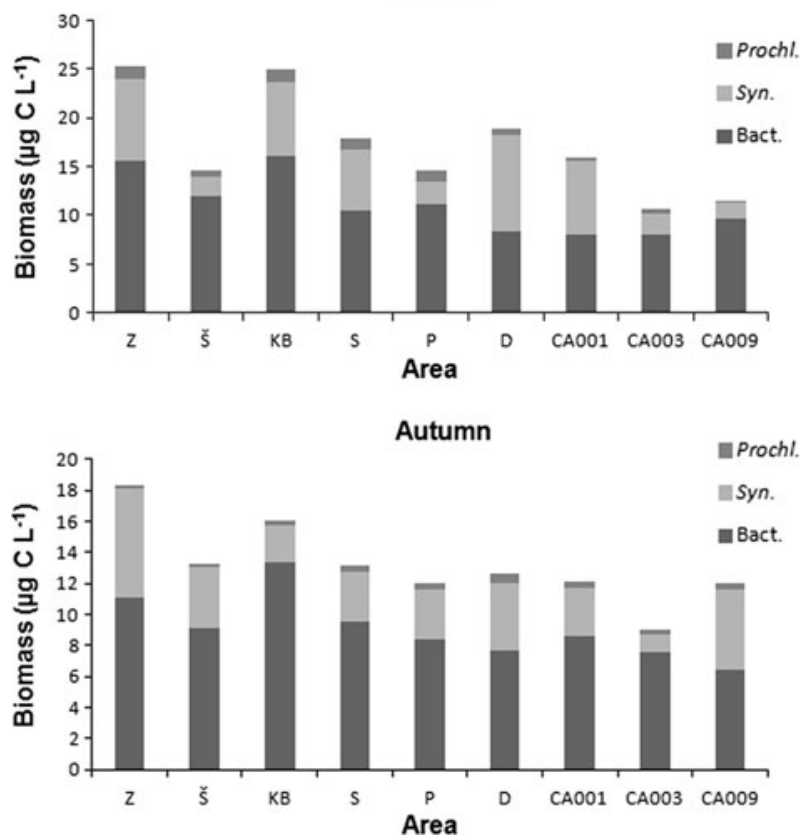

Fig. 5 Seasonal fluctuations of Synechococcus, Prochlorococcus and bacterial biomasses. Coastal areas: Zadar (Z), Šibenik (Š), Kaštela Bay (KB), Split (S), Ploče (P), Dubrovnik (D) and open sea stations (CA001, CA003, and CA009). Average values (stacked column) are presented

non-pigmented prokaryotes. Analysis of biomass in the prokaryotic community usually shows an increase of autotrophic picoplankton biomass in investigated sites, as well as in some research areas of the Mediterranean Sea, during the warmer season (Agawin et al. 2000). In relation to coastal areas, an increase of autotrophic prokaryotic

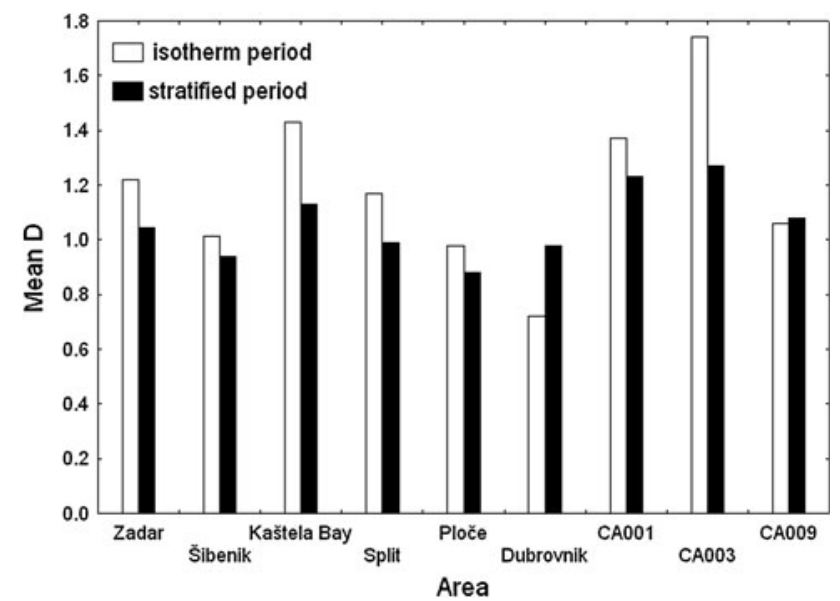

Fig. 6 Relationship between HNF and heterotrophic bacteria abundance according $\mathrm{D}$ values

biomass was found in the open sea as well as in the Mediterranean Sea (Magazzù and Decembri 1995). Within the autotrophic fraction, it was found that Synechococcus biomass as well as abundance predominated over Prochlorococcus, as reported in the literature for the summer period in the surface layers of the Mediterranean Sea (Llabrés et al. 2010). This can be compared with data from the Coral Sea (Crosbie and Furnas 2001), Pacific and the Atlantic (Zhang et al. 2008). However, our results are contrary to those from different regions of the Mediterranean Sea (Mella-Flores et al. 2011), where abundances of Prochlorococcus mostly predominated over Synechococcus. The difference in domination of Synechococcus over the Prochlorococcus densities in the investigated areas of the Adriatic Sea could be explained by the fact that generally genus Synechococcus is known as a eurythermal organism (Waterbury et al. 1986; Shapiro and Haugen 1988; Neuer 1992). It is adapted on water-column mixing (Lindell and Post 1995) and is able to consume different types of nitrogen and phosphorus sources, which possibly gives it an advantage over genus Prochlorococcus in the coastal study area of the Adriatic Sea.

Our results show that predation has an important role in the observed seasonal and spatial distributions of non-pigmented bacteria. We identified changes in the degree of predation as a type of control on the seasonal scale, in the coastal areas where bacteria were more controlled by HNF during the warmer period, as also reported by Šolić et al. (2009). On the spatial scale, our results show the strongest correlation between bacteria and HNF in the coastal area, especially in the region of Šibenik and Ploče, which is described as the area richest in nutrients (Cetinić et al. 2006; Svensen et al. 2007; Šolić et al. 2008). Our obtained results agree with Hobbie and Cole (1984) who highlighted the impact of predation by HNF in nutrient-rich environments. 
Table 3 Pearson's correlations between the nutrient concentrations, chlorophyll a, Prochlorococcus abundance and the abundance of nonpigmented bacteria (B) and bacterial production (BP) during isothermal and stratified water column period

\begin{tabular}{|c|c|c|c|c|c|c|c|c|}
\hline Complete data set & $\begin{array}{l}\text { Temperature } \\
\left({ }^{\circ} \mathrm{C}\right)\end{array}$ & Salinity & $\begin{array}{l}\text { Nitrate } \\
(\mu \mathrm{M})\end{array}$ & $\begin{array}{l}\text { Nitrite } \\
(\mu \mathrm{M})\end{array}$ & $\begin{array}{l}\text { Ammonium } \\
(\mu \mathrm{M})\end{array}$ & $\begin{array}{l}\text { SRP* } \\
(\mu \mathrm{M})\end{array}$ & $\begin{array}{l}\text { Prochlorococcus } \\
\left(\times 10^{3} \text { cells } \mathrm{mL}^{-1}\right)\end{array}$ & $\begin{array}{l}\text { Chl } a \\
\left(\mathrm{mg} \mathrm{m}^{-3}\right)\end{array}$ \\
\hline \multicolumn{9}{|c|}{ Coastal sea, $N=131, P<0.05$ (isothermal period) } \\
\hline Pearson's correlation with B & 0.24 & -0.22 & 0.09 & -0.07 & 0.05 & $-\mathbf{0 . 2 3}$ & 0.22 & 0.87 \\
\hline Pearson's correlation with BP & 0.09 & 0.06 & $-\mathbf{0 . 2 2}$ & -0.22 & 0.06 & 0.09 & $-\mathbf{0 . 3 7}$ & -0.26 \\
\hline \multicolumn{9}{|c|}{ Coastal sea, $N=239, P<0.05$ (stratified period) } \\
\hline Pearson's correlation with B & 0.12 & 0.01 & -0.14 & -0.26 & $-\mathbf{0 . 3 0}$ & 0.05 & 0.31 & -0.03 \\
\hline Pearson's correlation with BP & -0.01 & 0.01 & 0.02 & 0.14 & 0.05 & 0.04 & -0.15 & 0.04 \\
\hline \multicolumn{9}{|c|}{ Open sea, $N=45, P<0.05$ (isothermal period) } \\
\hline Pearson correlation with B & 0.19 & -0.13 & -0.26 & 0.22 & 0.10 & -0.10 & 0.51 & 0.21 \\
\hline Pearson's correlation with BP & 0.44 & -0.06 & $-\mathbf{0 . 5 3}$ & -0.26 & -0.04 & 0.09 & -0.14 & 0.68 \\
\hline \multicolumn{9}{|c|}{ Open sea, $N=103, P<0.05$ (stratified period) } \\
\hline Pearson's correlation with B & 0.14 & -0.18 & -0.32 & -0.02 & 0.22 & -0.27 & 0.29 & -0.08 \\
\hline Pearson's correlation with BP & -0.12 & -0.06 & -0.27 & 0.07 & -0.04 & -0.07 & -0.02 & -0.38 \\
\hline
\end{tabular}

Statistically significant correlations are presented bold

* SRP soluble reactive phosphate

In oligotrophic ecosystems, bacterial abundance is mostly controlled by the supply of nutrients (Cole et al. 1988; Ducklow 1992). According to the literature, the correlation between bacteria and phytoplankton excretion, like food source, is well known (Carlson et al. 1996; Kirchman and Rich 1997). Similar correlations with the concentration of chlorophyll $a$ determined in this paper have also been reported in previous papers for the oligotrophic central Adriatic (Krstulović et al. 1997; Šestanović et al. 2004). The very weak relationship between bacteria and inorganic nutrients obtained in this paper could be explained by the fact that, during the investigated period, the warmer and more saline Levantine Intermediate Water influenced the deep waters in the eastern middle Adriatic Sea. This brings higher concentrations of inorganic nutrients (Šolić et al. 2008), and therefore, bacterial expansion was not limited by low concentrations of inorganic nutrients.

\section{Conclusions}

The proportions of HNA bacteria in total abundance of nonpigmented bacteria were highest in those areas with the highest bacterial production (in the areas influenced by karstic rivers) and the higher bacterial densities, during all investigated seasons. In oligotrophic areas, the LNA group dominated for a period of high bacterial production, indicating the importance of both bacterial groups in bacterial production and activity. The biomass of nonpigmented prokaryotes was mostly predominant in the prokaryotic community. Within the autotrophic community, Synechococcus biomass mostly predominated. Predation of heterotrophic bacteria by HNF was pronounced during the warmer period in the coastal areas.

Acknowledgments This research was supported by the Croatian Ministry of Science, Education and Sport as part of the research program 'Role of plankton communities in the energy and matter flow in the Adriatic Sea '(project no 001-0013077-0845), also thank Barbara Zorica and Ivan Vučić to help.

\section{References}

Agawin NSR, Agustí S (1997) Abundance, frequency of dividing cells and growth rates of Synechococcus sp. (cyanobacteria) in the stratified Northwest Mediterranean Sea. J Plankton Res 19:1599-1615

Agawin NSR, Duarte CM, Agustí S (2000) Nutrient and temperature control of the contribution of picoplankton to phytoplankton biomass and production. Limnol Oceanogr 45:591-600

Andrade L, Gonzales AM, Rezende CE, Suzuki M, Valentin JL, Paranhos R (2007) Distribution of HNA and LNA bacterial groups in the Southwest Atlantic Ocean. Braz J Microbiol 38:330-336

Button DK (1998) Nutrient uptake by microorganisms according to kinetic parameters from theory as related to cytoarchitecture. Microbiol Mol Biol Rev 62:636-645

Calvo-Díaz A, Morán XAG (2006) Seasonal dynamics of picoplankton in shelf waters of the southern Bay of Biscay. Aquat Microb Ecol 42:159-174

Carlson CA, Ducklow HW, Sleeter TD (1996) Stocks and dynamics of bacterioplankton in the northwester Sargasso Sea. Deep-Sea Res II 4:491-516

Casotti R, Brunet C, Aronne B, D’Alcalà MR (2000) Mesoscale features of phytoplankton and planktonic bacteria in a coastal area as induced by external water masses. Mar Ecol Prog Ser 195:15-27

Cetinić I, Viličić D, Burić Z, Olujić G (2006) Phytoplankton seasonality in a highly stratified karstic estuary (Krka, Adriatic Sea). Hydrobiologia 555:31-40 
Chisholm SW, Olson RJ, Zettler ER, Waterbury JB, Goericke R, Welschmeyer N (1988) A novel free-living prochlorophyte occurs at high cell concentrations in the oceanic euphotic zone. Nature 334:340-343

Cole JJ, Findlay S, Pace ML (1988) Bacterial production in fresh and saltwater ecosystems: a cross-system overview. Mar Ecol Prog Ser 43:1-10

Cotner JB, Biddanda BA (2002) Small players, large role: microbial influence on auto-heterotrophic coupling and biogeochemical processes in aquatic ecosystems. Ecosystems 5:105-121

Crosbie ND, Furnas MJ (2001) Abundance, distribution and flowcytometric characterization of picophytoprokaryote populations in central $\left(17^{\circ} \mathrm{S}\right)$ and southern $\left(20^{\circ} \mathrm{S}\right)$ shelf waters of the Great Barrier Reef. J Plankton Res 23:809-828

Ducklow HW (1992) Factors regulating bottom-up control of bacterial biomass in open ocean plankton communities. Archiv für Hydrobiologie, Organ der Internationalen Vereinigung für Theoretische und Angewandte Limnologie, Beihefte. Ergebnisse der Limnologie 37:207-217

Ducklow HW, Purdie DA, Williams PJL, Davis JM (1986) Bacterioplankton: a sink for carbon in a coastal marine plankton community. Science 232:865-867

Fuhrman JA, Azam F (1982) Thymidine incorporation as a measure of heterotrophic bacterioplankton production in marine surface waters. Mar Biol 66:109-120

Fuks D, Radić J, Radić T, Najdek M, Blažina M, Degobbis D, Smodlaka N (2005) Relationships between heterotrophic bacteria and cyanobacteria in the northern Adriatic in relation to the mucilage phenomenon. Sci Total Environ 353:178-188

Gasol JM (1994) A framework for the assessment of top-down vs. bottom-up control of heterotrophic nanoflagellates abundance. Mar Ecol Prog Ser 113:291-300

Gasol JM, Del Giorgio PA (2000) Using flow cytometry for counting natural planktonic bacteria and understanding the structure of planktonic bacterial communities. Sci Mar 64:197-224

Gasol JM, Morán XAG (1999) Effects of filtration on bacterial activity and picoplankton community structure as assessed by flow cytometry. Aquat Microb Ecol 16:251-264

Grasshof K (1976) Methods of seawater analysis. Verlag Chemie, Weinhein

Grégori G, Citterio S, Ghiani A, Labra M, Scorbati SB, Denis M (2001) Resolution of viable and membrane-compromised bacteria in fresh water and marine waters based on analytical flow cytometry and nucleic acid double staining. Appl Environ Microbiol 67:4662-4670

Hobbie JE, Cole JJ (1984) Response of a detrital foodweb to eutrophication. B Mar Sci 35:357-363

Jochem FJ (2001) Morphology and DNA content of bacterioplankton in the northern Gulf of Mexico: analysis by epifluorescence microscopy and flow cytometry. Aquat Microb Ecol 25:179-194

Jochem FJ, Lavrentyev PJ, First MR (2004) Growth and grazing rates of bacteria groups with different apparent DNA content in the Gulf of Mexico. Mar Biol 145:1213-1225

Jürgens K, Matz C (2002) Predation as a shaping force for the phenotypic and genotypic composition of planktonic bacteria. Antonie Leeuwenhoek 81:413-434

Kirchman DL, Rich JH (1997) Regulation of bacterial growth rates by dissolved organic carbon and temperature in the equatorial Pacific Ocean. Microb Ecol 33:11-20

Kjelleberg S, Albertson N, Flaerdh K, Holmquist L, Jouper-Jaan A, Marouga R, Oestling J, Svenblad B, Weichart D (1993) How do nondifferentiating bacteria adapt to starvation? Antonie Leeuwenhoek 63:333-341

Krstulović N (1992) Bacterial biomass and production rates in the central Adriatic. Acta Adriat 33:49-65
Krstulović N, Šolić M, Marasović I (1997) Relationship between bacteria, phytoplankton and heterotrophic nanoflagellates along the trophic gradient. Helgöl Mar Res 51:433-443

Li WKW, Dickie PM (2001) Monitoring phytoplankton, bacterioplankton and virioplankton in a coastal inlet (Bedford Basin) by flow cytometry. Cytometry 44:236-246

Li WKW, Jellett JF, Dickie PM (1995) DNA distribution in planktonic bacteria stained with TOTO or TO-PRO. Limnol Oceanogr 40:1485-1495

Lindell D, Post AF (1995) Ultraphytoplankton succession is triggered by deep winter mixing in the Gulf of Aqaba (Eilat), Red Sea. Limnol Oceanogr 40:1130-1141

Llabres M, Agustí S, Alonso-Laita P, Herndl GJ (2010) Synechococcus and Prochlorococcus cell death induced by UV radiation and the penetration of lethal UVR in the Mediterranean Sea. Mar Ecol Prog Ser 399:27-37

Longnecker K, Sherr BF, Sherr EB (2005) Activity and phylogenetic diversity of bacterial cells with high and low nucleic acid content and electron transport system activity in an upwelling ecosystem. Appl Environ Microb 71:7737-7749

Longnecker K, Sherr BF, Sherr EB (2006) Variation in cell-specific rates of leucine and thymidine incorporation by marine bacteria with high and with low nucleic acid content off the Oregon coast. Aquat Microb Ecol 43:113-125

Magazzù G, Decembri F (1995) Primary production, biomass and abundance of phototrophic picoplankton in the Mediterranean Sea: a review. Aquat Microb Ecol 9:97-104

Marasović I, Ninčević-Gladan Ž, skejić S, Bužančić M (2006) Biološke osobine u Kušpilić G i sur. Kontrola kakvoće obalnog mora (Projekt Vir-Konavle 2005). Studije i elaborati Instituta za oceanografiju i ribarstvo, Split, pp 68-81

Marie D, Partensky F, Jacquet S, Vaulot D (1997) Enumeration and cell cycle analysis of natural populations of marine picoplankton by flow cytometry using the nucleic acid stain SYBR Green I. Appl Environ Microb 63:186-193

Mary I, Heywood JL, Fuchs BM, Amann R, Burkill PH, Tarran GA, Zubkov MV (2006) SAR11 dominance among metabolically active low nucleic acid bacterioplankton in surface waters along an Atlantic meridional transect. Aquat Microb Ecol 45:107-113

Mella-Flores D, Mazard S, Humily F et al (2011) Is the distribution of Prochlorococcus and Synechococcus ecotypes in the Mediterranean Sea affected by global warming? Biogeosciences 8:27852804

Mével G, Vernet M, Goutx M, Ghiglione JF (2008) Seasonal to hour variation scales in abundance and production of total and particle-attached bacteria in the open NW Mediterranean Sea (0-1000 m). Biogeosciences 5:1573-1586

Morán XAG, Gasol JM, Pedrós-Alió C, Estrada M (2002) Partitioning of phytoplanktonic organic carbon production and bacterial production along a coastal-offshore gradient in the NE Atlantic during different hydrographic regimes. Aquat Microb Ecol 29:239-252

Morán XAG, Fernández E, Pérez V (2004) Size-fractionated primary production, bacterial production and net community production in subtropical and tropical domains of the oligotrophic NE Atlantic in autumn. Mar Ecol Prog Ser 274:17-29

Morán XAG, Bode A, Suárez LÁ, Nogueira E (2007) Assessing the relevance of nucleic acid content as an indicator of marine bacterial activity. Aquat Microb Ecol 46:141-152

Morović M i sur (2006) Fizikalne i kemijske osobine u Kušpilić G i sur. Kontrola kakvoće obalnog mora (Projekt Vir-Konavle 2005). Studije i elaborati Instituta za oceanografiju i ribarstvo, Split, pp 29-46

Neuer S (1992) Growth dynamics of marine Synechococcus spp in the Gulf of Alaska. Mar Ecol Prog Ser 83:251-262 
Ninčević Gladan Ž, Marasović I, Kušpilić G, Krstulović N, Šolić M, Šstanović S (2006) Abundance and composition of picoplankton in the mid Adriatic Sea. Acta Adriatic 47:127-140

Olson RJ, Zettler ER, DuRand MD (1993) Handbook of methods in aquatic microbial ecology. In: Kemp PF, Sherr BF, Sherr EV, Cole JJ (eds) Phytoplankton analysis using flow cytometry. Lewis Publishers, Boca Raton

Porter KG, Feig YS (1980) The use of DAPI for identifying and counting aquatic microflora. Limnol Oceanogr 25:943-948

Radić T, Šilović T, Šantić D, Fuks D, Mičić M (2009) Preliminary flow cytometric analyses of phototrophic pico-and nanoplankton communities in the Northern Adriatic. Fresenius Environ Bull $18: 715-724$

Riemann B, Bjorsen PK, Newell S, Fallon R (1987) Calculation of cell production of coastal marine bacteria based on measured incorporation of (H)thymidine. Limnol Oceanogr 32:471-476

Šantić D, Krstulović N, Šolić M, Kušpilić G (2011) Distribution of Synechococcus and Prochlorococcus in the central Adriatic Sea. Acta Adriatic 52:101-114

Schattenhofer M, Wulf J, Kostadinov I, Glöckner FO, Zubkov MV, Fuchs BM (2011) Phylogenetic characterisation of picoplanktonic populations with high and lownucleic acid content in the North Atlantic Ocean. Syst Appl Microbiol 34:470-475

Šestanović S, Šolić M, Krstulović N, Ninčević Ž (2004) Seasonal and vertical distribution of planktonic bacteria and heterotrophic nanoflagellates in the middle Adriatic Sea. Helgöl Mar Res 58:83-92

Shapiro LP, Haugen EM (1988) Seasonal distribution and tolerance of Synechococcus in Boothbay harbor. Maine Estuar Coast Shelf Sci 26:517-525

Šilović T, Ljubešić Z, Mihanović H, Olujić G, Terzić S, Jakšić Ž, Viličić D (2011) Picoplankton composition related to thermohaline circulation: the Albanian boundary zone (southern Adriatic) in late spring. Estuar Coast Shelf Sci 91:519-525

Šimek K, Chrzanowski TH (1992) Direct and indirect evidence of the size selective grazing on pelagic bacteria by freshwater nanoflagellates. Appl Environ Microb 58:3715-3720

Šolić M, Krstulović N, Šestanović S (2001) The roles of predation, substrate suply and temperature in controlling bacterial abundance: interaction between spatial and seasonal scale. Acta Adriatic 42:35-48

Šolić M, Krstulović N, Vilibić I, Kušpilić G, Šestanović S, Šantić D, Ordulj M (2008) The role of water mass dynamics in controlling bacterial abundance and production in the middle Adriatic Sea. Mar Environ Res 65:388-404

Šolić M, Krstulović N, Vilibić I, Bojanić N, Kušpilić G, Šestanović S, Šantić D, Ordulj M (2009) Variability in the bottom-up and topdown control of bacteria on trophic and temporal scale in the middle Adriatic Sea. Aquat Microb Ecol 58:15-29

Svensen C, Viličić D, Wassmann P, Arashkevich E, Ratkova T (2007) Plankton distribution and vertical flux of biogenic matter during high summer stratification in the Krka estuary (Eastern Adriatic). Estuar Coast Shelf Sci 71:381-390

Waterbury JB, Watson S, Guillard RRL, Brand LE (1979) Widespread occurrence of a unicellular, marine, planktonic, cyanobacterium. Nature 277:293-294

Waterbury JB, Watson S, Valois FW, Franks DG (1986) Biological and ecological characterization of the marine unicellular cyanobacterium Synechococcus. Can J Fish Aquat Sci 214:71-120

Zhang Y, Jiao NZ, Hong N (2008) Comparative study of picoplankton biomass and community structure in different provinces from subarctic to subtropical oceans. Deep-Sea Res II 55:1605-1614

Zubkov MV, Fuchs BM, Burkill PH, Amann R (2001) Comparison of cellular and biomass specific activities of dominant bacterioplankton groups in stratified waters of the Celtic Sea. Appl Environ Microb 67:5210-5218

Zubkov MV, Allen JI, Fuchs BM (2004) Coexistence of dominant groups in marine bacterioplankton community-a combination of experimental and modelling approaches. J Mar Biol Assoc UK 84:519-529

Zubkov MV, Tarran GA, Burkill PH (2006) Bacterioplankton of low and high DNA content in the suboxic waters of the Arabian Sea and the Gulf of Oman: abundance and amino acid uptake. Aquat Microb Ecol 43:23-32

Zweifel UL, Hagström $\AA$ (1995) Total counts of marine bacteria include a large fraction of non-nucleoid-containing bacteria (ghosts). Appl Environ Microb 61:2180-2185 